\title{
O CONTEÚDO NORMATIVO DOS PRINCÍPIOS ORIENTADORES DA MEDIAÇÃO
}

\author{
Danilo Christiano Antunes Meira \\ Doutorando em Direito pela Universidade Federal de Santa \\ Catarina (UFSC). Mestre em Direito pela UFSC. Graduado \\ em Direito pela Faculdade de Direito Santo Agostinho \\ (FADISA). Membro do grupo de pesquisa Núcleo de \\ Estudos Conhecer Direito (NECODI, IMED/Passo Fundo). \\ Bolsista CNPq. \\ E-mail: danchristiano@gmail.com.
}

\section{Horácio Wanderlei Rodrigues}

Doutor em Direito (Filosofia do Direito e da Política) pela Universidade Federal de Santa Catarina (UFSC). Mestre em Direito (Instituições Jurídico-Políticas) pela UFSC. Realizou Estágios de Pós-Doutorado em Filosofia na Universidade do Vale do Rio dos Sinos (UNISINOS) e em Educação na Universidade Federal do Rio Grande do Sul (UFRGS). Professor Permanente do Programa de PósGraduação em Direito (PPGD) da Faculdade Meridional (IMED/RS). Professor Titular de Teoria do Processo do Departamento de Direito e Professor Permanente do Programa de Pós-Graduação Direito da UFSC, de 1991 a 2016. Coordenador do Mestrado Profissional em Direito da UFSC, de 2015 a 2016. Sócio fundador do Conselho Nacional de Pesquisa e Pós-Graduação em Direito (CONPEDI) e da Associação Brasileira de Ensino do Direito (ABEDi). Membro do Instituto Iberomericano de Derecho Procesal (IIDP). Pesquisador do Conselho Nacional de Desenvolvimento Científico e Tecnológico $(\mathrm{CNPq})$ e da Fundação Meridional. Presidente da Comissão de Educação Jurídica da OAB/SC.

E-mail: horaciowr@gmail.com

RESUMO: Este artigo tem o objetivo de indicar as possíveis normas que podem ser extraídas dos princípios orientadores da mediação. A análise é feita por uma abordagem semântica e sistemática dos enunciados. Além disso, busca identificar quais princípios são aplicáveis às modalidades judicial e extrajudicial da mediação. Os princípios analisados são aqueles instituídos pelos marcos normativos da mediação: autonomia da vontade, boa-fé, busca do consenso, competência, confidencialidade, decisão informada, empoderamento, imparcialidade, independência, informalidade, isonomia entre as partes, oralidade, respeito à ordem pública e às leis vigentes e validação. Como conclusão, indica as principais dificuldades que devem ser enfrentadas pelos atores envolvidos no procedimento da mediação.

PALAVRAS-CHAVE: Mediação; Princípios orientadores; Conteúdo normativo. 


\title{
The normative content of the guiding principles of mediation
}

\begin{abstract}
This article aims to indicate the possible norms that can be extracted from the guiding principles of mediation. The analysis is performed by a semantic and systematic approach to statements. In addition, it seeks to identify which principles apply to the judicial and extrajudicial modalities of mediation. The principles analyzed are those established by the normative frameworks of mediation: autonomy of the will, good faith, the search for consensus, competence, confidentiality, informed decision, empowerment, impartiality, independence, informality, isonomy, orality. respect for public order and the laws in force and validation. In conclusion, it indicates the main difficulties that must be faced by the actors involved in the mediation procedure.
\end{abstract}

KEYWORDS: Mediation; Guiding principles; Normative content.

\section{INTRODUÇÃOO}

O objetivo do presente artigo é responder uma pergunta relativamente simples: identificar as normas que podem ser extraídas dos enunciados que estabeleceram os princípios orientadores da mediação entre particulares no âmbito civil. As questões que justificam o desenvolvimento de um estudo com essa proposta, por outro lado, derivam de problemas mais difíceis: os embaraços causados aos atores envolvidos na mediação pelo fato desse procedimento ser disciplinado por três marcos normativos diferentes e as possíveis incompreensões a respeito das implicações práticas dos princípios que eles trazem.

Considerando que cada um dos princípios poderia ser tomado como objeto de extensos estudos autônomos, foi necessário empreender recortes e escolhas metodológicas para que este trabalho se tornasse ao mesmo tempo relevante e didático no escopo de um único artigo. São recortes e escolhas que precisam ser expostas para que o desenvolvimento da pesquisa e o seu resultado sejam compreendidos adequadamente.

Em primeiro lugar, optou-se por uma análise eminentemente semântica e sistemática dos enunciados que estabeleceram os princípios ${ }^{1}$. Dessa análise do significado e do contexto de um enunciado em relação aos outros é que foram indicadas as normas que podem ser compreendidas de um modo suficientemente aceitável. Em outras palavras, a tarefa principal dessa pesquisa se resume em apontar quais são os deveres ou direitos que cada princípio pode instituir sem malabarismos hermenêuticos.

\footnotetext{
1 Na qualidade de pesquisadores e acadêmicos, os autores deste artigo fazem a opção de limitar o trabalho a uma análise cognoscitiva das normas que compõem o objeto de estudo. Trata-se de um tipo de abordagem defendida por autores como Hans Kelsen, para quem uma análise científica do Direito positivo "é pura determinação cognoscitiva do sentido das normas jurídicas. Diferentemente da interpretação feita pelos órgãos jurídicos, ela não é criação jurídica”. Nessa concepção, "a interpretação jurídico-científica não pode fazer outra coisa senão estabelecer as possíveis significações de uma norma jurídica. Como conhecimento do seu objeto, ela não pode tomar qualquer decisão entre as possibilidades por si mesma reveladas, mas tem de deixar tal decisão ao órgão que, segundo a ordem jurídica, é competente para aplicar o Direito". Além disso, "uma interpretação estritamente científica de uma lei estadual ou de um tratado de Direito internacional que, baseada na análise crítica, revele todas as significações possíveis, mesmo aquelas que são politicamente indesejáveis e que, porventura, não foram de forma alguma pretendidas pelo legislador ou pelas partes que celebraram o tratado, mas que estão compreendidas na fórmula verbal por eles escolhida, pode ter um efeito prático que supere de longe a vantagem política da ficção do sentido único: É que uma tal interpretação científica pode mostrar à autoridade legisladora quão longe está a sua obra de satisfazer à exigência técnico-jurídica de uma formulação de normas jurídicas o mais possível inequívocas ou, pelo menos, de uma formulação feita por maneira tal que a inevitável pluralidade de significações seja reduzida a um mínimo e, assim, se obtenha o maior grau possível de segurança jurídica" (KELSEN, Hans. Teoria Pura do Direito. 6. ed. Trad. João Baptista Machado. São Paulo: Martins Fontes. 1998).
} 
Esse caráter de mera possibilidade deve ser enfatizado pelo fato de não se ter aqui a pretensão de afirmar categoricamente quais são as formas corretas de se interpretar um dado princípio e nem de inviabilizar outras formas de interpretá-lo. A regulamentação da mediação no âmbito civil é um fato relativamente novo para se falar em sistematização de interpretações autênticas, sedimentadas pela própria prática jurídica. Obviamente, mesmo assumindo que os critérios de escolha dos significados tenham sido o uso corrente e o uso jurídico dos termos, os conteúdos normativos foram expostos no artigo apenas naquilo em que os seus autores conseguiram alcançar em termos semânticos e que, ao mesmo tempo, consideraram razoável.

Em segundo lugar, foi preciso deixar de fora todos os princípios que regulamentam a mediação de forma indireta, como os princípios constitucionais, os princípios gerais do código de processo civil e os princípios gerais do código de direito civil. Essa escolha não deve ser compreendida como um indicativo de que esses princípios poderiam ter uma relevância inferior em relação à mediação. Eles não foram abordados simplesmente porque não cabia tudo aqui. Essa também é a razão pela qual foi feita a opção de não abordar o desenvolvimento histórico ou aspectos teóricos e filosóficos dos princípios. Não haveria espaço para fazer qualquer levantamento desses aspectos de modo satisfatório.

Por fim, com o objetivo de facilitar tanto a sua assimilação integral como consultas específicas a cada princípio, a organização do artigo é feita da forma mais simples e intuitiva possível. O primeiro tópico serve para situar o leitor sobre quais foram os princípios orientadores instituídos pelos três marcos normativos da mediação e o alcance que cada um deles tem em relação às modalidades judicial e extrajudicial da mediação. Tal exposição, feita em um tópico específico, serve para evitar que essa informação seja sempre repetida na análise individual de cada princípio. No segundo tópico é que se desenvolve a análise propriamente dita do conteúdo normativo dos princípios. Na conclusão são feitas algumas considerações sobre os pontos mais sensíveis que o estudo tornou evidente.

\section{A Abrangência dos Marcos Normativos da Mediação e DOS SEUS PRINCÍPIOS ORIENTADORES}

Como já se discutiu em outra publicação ${ }^{2}$, a mediação entre particulares no âmbito civil é regulamentada simultaneamente pela Resolução n. 125/2010 do CNJ, pelo Código de Processo Civil e pela Lei da Mediação. Cada um deles institui um conjunto específico de princípios.

De acordo com a Resolução n. 125/2010 do CNJ, os "princípios fundamentais que regem a atuação de conciliadores e mediadores judiciais" são: "confidencialidade, decisão informada, competência, imparcialidade, independência e autonomia, respeito à ordem pública e às leis vigentes, empoderamento e validação"3.

No Código de Processo Civil, os princípios informadores da mediação - e também da conciliação - são "os princípios da independência, da imparcialidade, da autonomia da vontade,

2 MEIRA, Danilo Christiano Antunes. RODRIGUES, Horácio Wanderlei. Os marcos normativos da mediação entre particulares no âmbito civil: escopo e relações de complementariedade, subsidiariedade e incompatibilidade. R. Jur. FA7, Fortaleza, v. 13, n. 2, p. 117-137, jul./dez. 2016.

3 CNJ. Resolução no 125, de 29 de novembro de 2010. Dispõe sobre a Política Judiciária Nacional de tratamento adequado dos conflitos de interesses no âmbito do Poder Judiciário e dá outras providências. Disponível em <http:// www.cnj.jus.br/busca-atos-adm?documento=2579>. Acesso em 13 mai. 2017 [Anexo III - Código de Ética de Conciliadores e Mediadores Judiciais, art. $1^{\circ}$ ]. 
da confidencialidade, da oralidade, da informalidade e da decisão informada"4. Os princípios orientadores da mediação trazidos pela Lei da Mediação são a imparcialidade do mediador, a isonomia entre as partes, a oralidade, a informalidade, a autonomia da vontade das partes, a busca do consenso, a confidencialidade e a boa-fés .

Alguns princípios, portanto, são comuns aos três marcos normativos, alguns outros se repetem em apenas dois marcos normativos e outros existem em apenas um. Além da multiplicidade de marcos normativos e da não-coincidência dos conjuntos de princípios orientadores, existe uma dificuldade adicional que os atores envolvidos na mediação precisam levar em conta para saber quais princípios devem ser observados no caso concreto e quais não: o fato de os marcos não possuírem a mesma abrangência em relação às modalidades judicial e extrajudicial da mediação.

Resumidamente, a Resolução n. 125/2010 do CNJ regulamenta apenas a mediação judicial $^{6}$, a Lei da Mediação regulamentam tanto a mediação judicial como a extrajudicial ${ }^{7}$ e o Código de Processo Civil regulamenta a mediação judicial realizada tanto nos centros judiciários de solução de conflitos como nas câmaras privadas (no que couber), ficando, porém, controvertida a sua aplicabilidade à modalidade extrajudicial realizada nas câmaras privadas (existem argumentos razoáveis que sustentam respostas positivas ou negativas ${ }^{8}$ ).

4 BRASIL. Lei $\mathbf{n}^{\circ} \mathbf{1 3 . 1 0 5}$, de 16 de março de 2015. Código de Processo Civil. Publicado no Diário Oficial da União de 17 de março de 2015. Disponível em <http://www.planalto.gov.br/ccivil_03/_ato2015-2018/2015/lei/113105.htm>. Acesso em 13 mai. 2017. Art. 166.

5 BRASIL. Lei no 13.140, de 26 de junho de 2015. Dispõe sobre a mediação entre particulares como meio de solução de controvérsias e sobre a autocomposição de conflitos no âmbito da administração pública. Publicada no Diário Oficial da União de 29 de junho de 2015. Disponível em <http://www.planalto.gov.br/ccivil_03/_Ato2015-2018/ 2015/Lei/L13140.htm>. Acesso em 13 mai. 2017. Art. 2a , incisos I a VIII.

6 Sobre a abrangência dos princípios trazidos pela da Resolução n. 125/2010 do CNJ em relação às modalidades judicial e extrajudicial da mediação, é importante notar que os mesmos foram elencados no art. $1^{\circ}$ Anexo III da resolução intitulada de Código de Ética dos Conciliadores e Mediadores Judiciais e que foram nomeados como "princípios fundamentais que regem a atuação de conciliadores e mediadores judiciais". Além disso, como já observado em outra oportunidade, os atos regulamentares do CNJ só podem vincular os atores envolvidos na mediação que estejam hierarquicamente subordinados ao CNJ (MEIRA; RODRIGUES, 2016, p. 124-125). Como consequência, é de se concluir que a modalidade extrajudicial da mediação não é alcançada pela Resolução n. 125/2010 do CNJ.

7 Dado que a Lei da Mediação dispõe explicitamente "sobre a mediação como meio de solução de controvérsias entre particulares" (art. $1^{\circ}$ ) nas modalidades judicial (art. 24 e ss.) e extrajudicial (art. 21 e ss.), e estando os princípios orientadores localizados em seção de disposições gerais, não parece haver dúvida sobre o fato de que tais princípios devem ser observados nas modalidades judicial e extrajudicial de mediação. Além disso, por expressa disposição, tais princípios são aplicáveis, "no que couber, às outras formas consensuais de resolução de conflitos, tais como mediações comunitárias e escolares, e àquelas levadas a efeito nas serventias extrajudiciais, desde que no âmbito de suas competências" (art. 42).

8 Considerando que a seção dedicada à conciliação e mediação leva o nome Dos Conciliadores e Mediadores Judiciais, é intuitivo concluir que o Código de Processo Civil buscou disciplinar apenas a mediação judicial. Essa conclusão é reforçada pelo fato de tal seção encerrar-se com um artigo que prescreve que as disposições nela contidas não excluem "outras formas de conciliação e mediação extrajudiciais vinculadas a órgãos institucionais ou realizadas por intermédio de profissionais independentes, que poderão ser regulamentadas por lei específica" (art. 175). Não excluir é diferente de regulamentar, e uma lei específica que regulamenta a mediação extrajudicial é a própria Lei da Mediação. Todavia, a afirmação de que o Código de Processo Civil regulamenta apenas a modalidade judicial da mediação pode ser questionada por algumas razões, pelo menos em relação à mediação realizada nas câmaras privadas. Por padrão, o Código de Processo Civil, embora permitindo aos tribunais a criação de quadro próprio de conciliadores e mediadores ou a designação de terceiros, cadastrados ou não (art. 168, $\$ 1^{\circ}$ ), para atuar nos centros judiciários de solução de conflitos, buscou estimular a realização da mediação em câmaras privadas (art. 167). Todos esses casos (procedimentos conduzidos por servidor ou por terceiro, em CEJUSC ou em câmara privada), se iniciados como etapa de ação judicial em curso, configuram a modalidade judicial da mediação. Ocorre que as câmaras privadas também podem oferecer serviços de mediação a pessoas que não judicializaram o conflito. E o enunciado do Código de Processo Civil que estabelece que as disposições sobre a mediação são aplicáveis, "no que couber, às câmaras privadas de conciliação e mediação" (art. 175, parágrafo único), por não ser suficientemente específica, abre margem para uma interpretação que inclua na regulamentação também a mediação realizada por câmara privada contratada por particulares que não 
Para facilitar a percepção e a superação das dificuldades, organizou-se abaixo um quadro que sintetiza todas as informações relevantes para a tomada de decisão:

Tabela 4 - Comparativo dos princípios adotados para a mediação pela legislação

\begin{tabular}{|c|c|c|}
\hline Lei da Mediação & Código de Processo Civil & $\begin{array}{l}\text { Resolução no 125/ } \\
2010 \text { do CNJ }\end{array}$ \\
\hline $\begin{array}{l}\text { Aplicável à mediação judicial, à } \\
\text { mediação extrajudicial e, no que } \\
\text { couber, às outras formas consen- } \\
\text { suais de resolução de conflitos, } \\
\text { tais como mediações comunitá- } \\
\text { rias e escolares, e àquelas levadas } \\
\text { a efeito nas serventias extrajudi- } \\
\text { ciais }\end{array}$ & $\begin{array}{l}\text { Aplicável à mediação judicial reali- } \\
\text { zada nos centros judiciários de solução } \\
\text { consensual de conflitos. No que cou- } \\
\text { ber, são aplicáveis à mediação judicial } \\
\text { realizada nas câmaras privadas. A apli- } \\
\text { cabilidade em relação a mediação ex- } \\
\text { trajudicial realizada nas câmaras priva- } \\
\text { das é controversa }\end{array}$ & $\begin{array}{l}\text { Aplicável à media- } \\
\text { ção judicial }\end{array}$ \\
\hline $\begin{array}{l}\text { Autonomia da vontade (das par- } \\
\text { tes) }\end{array}$ & Autonomia da vontade & \\
\hline \multicolumn{3}{|l|}{ Boa-fé } \\
\hline \multicolumn{3}{|l|}{ Busca do consenso } \\
\hline & & Competência \\
\hline \multirow[t]{3}{*}{ Confidencialidade } & Confidencialidade & Confidencialidade \\
\hline & Decisão informada & Decisão informada \\
\hline & & Empoderamento \\
\hline \multirow[t]{2}{*}{ Imparcialidade (do mediador) } & Imparcialidade & Imparcialidade \\
\hline & Independência & $\begin{array}{l}\text { Independência (e } \\
\text { autonomia) }\end{array}$ \\
\hline Informalidade & Informalidade & \\
\hline \multicolumn{3}{|l|}{ Isonomia entre as partes } \\
\hline \multirow[t]{3}{*}{ Oralidade } & Oralidade & \\
\hline & & $\begin{array}{l}\text { Respeito à ordem } \\
\text { pública e às leis vi- } \\
\text { gentes }\end{array}$ \\
\hline & & Validação \\
\hline
\end{tabular}

Fonte: elaborado pelos autores.

judicializaram o conflito. Portanto, ainda que seja razoável afirmar que interpretação sistemática dos dispositivos reforce a conclusão de que a atuação das câmaras privadas regulamentada pelo Código de Processo Civil seja apenas a judicial, operada mediante convênio com os tribunais, também parece razoável afirmar que a redação do art. 175 , parágrafo único, dá margens para uma interpretação que estabeleça a obrigatoriedade das câmaras privadas observarem a regulamentação do Código de Processo Civil na condução da mediação judicial e extrajudicial. 


\section{O Conteúdo Normativo dos Princípios Orientadores}

Identificados os marcos normativos que regulamentam a mediação, os princípios orientadores que eles instituíram e a abrangência dos mesmos em relação às modalidades judicial e extrajudicial da mediação, torna-se possível analisar o conteúdo normativo de cada um dos princípios que devem ser observados pelos atores envolvidos no procedimento da mediação.

A análise que se privilegia aqui é eminentemente semântica e sistemática. Busca identificar os direitos e deveres instituídos pelos princípios orientadores a partir dos significados dos respectivos enunciados e da relação destes com outros enunciados conexos.

\subsection{Princípio da autonomia da vontade}

O princípio da autonomia está previsto no Código de Processo Civil ${ }^{9}$ e na Lei da Mediação (como princípio da autonomia da vontade das partes) ${ }^{10}$. É um princípio que não apenas orienta, mas também reflete as principais características do instituto. Em sentido amplo, tal como disposto no Vocabulário Jurídico do STJ, ele pode ser compreendido como um princípio "que confere aos contratantes o poder de autorregulamentação de seus interesses, desde que se submetam às normas jurídicas, e seus fins não contrariem o interesse geral, de tal sorte que a ordem pública e os bons costumes constituam limites à liberdade contratual" ${ }^{11}$.Em sentido estrito e próprio da mediação, o conteúdo normativo do princípio da autonomia da vontade pode ser compreendido a partir de outras normas que o Código de Processo Civil e a Lei da Mediação estabeleceram.

Em primeiro lugar, encontram-se no âmbito da autonomia da vontade as normas que prescrevem que a mediação só ocorrerá se as partes não demonstrarem desinteresse pela composição consensual $^{12}$ e que nenhuma parte será obrigada a permanecer no procedimento ${ }^{13}$. Em segundo lugar, também diz respeito ao princípio da autonomia da vontade a norma que permite que o próprio procedimento da mediação seja alterado por vontade das partes, para ajustá-lo às especificidades do conflito ${ }^{14}$. Por fim, o conteúdo material do acordo que a mediação favorece é apenas aquele alcançado pela convergência voluntária dos interesses das próprias partes, o que significa que esse acordo não poderá ser imposto por uma das partes ou pelo mediador ${ }^{15}$.

É importante observar, a propósito, que a autonomia da vontade não é soberana no Direito contemporâneo. No procedimento da mediação, ela é limitada em muitos aspectos. Para uma exposição didática, é possível classificar tais limitações em três diferentes dimensões: interpessoais, internas e externas. As limitações interpessoais dizem respeito ao fato das proposições de acordo e alterações procedimentais sugeridas por uma das partes, no âmbito de sua respectiva autonomia, serem limitadas pela autonomia da parte adversária. As limitações internas, por sua

9 Código de Processo Civil, art. 166.

${ }^{10}$ Lei da Mediação, art. $2^{\circ}$, V.

${ }^{11}$ STJ. Princípio da autonomia da vontade das partes. Vocabulário Jurídico. Disponível em <http://www.stj.jus.br/ SCON/servlet/ThesMain?action=consultar\&pesquisa=PRINC\%CDPIO\%20DA\%20AUTONO-

MIA\%20DA\%20VONTADE\%20DAS\%20PARTES> Acesso em: 22 out. 2016.

12 O Código de Processo Civil prevê a hipótese de não realização da audiência de mediação quando ambas as partes, inclusive litisconsortes, manifestarem desinteresse pela composição consensual (art. 334, §4 $4^{\circ}$, I). O autor manifesta desinteresse na petição inicial e o réu manifesta desinteresse em petição avulsa protocolada com 10 dias de antecedência da audiência (art. $334, \S 5^{\circ}$ ).

13 É o que estabelece o art. $2^{\circ}, \S 2^{\circ}$, da A Lei da Mediação.

${ }^{14}$ Código de Processo Civil, arts. 166, $\$ 4^{\circ}$ e 190.

${ }^{15}$ Código de Processo Civil, art. 165, $\$ 3^{\circ}$. 
vez, são constituídas por outros dispositivos dos próprios marcos normativos da mediação (a Resolução no 125/2010 do CNJ, a Lei da Mediação e o Código de Processo Civil).

A possibilidade de alterações no procedimento de mediação, por exemplo, pode ser recusada pelo juiz, de ofício ou mediante requerimento, "nos casos de nulidade ou de inserção abusiva em contrato de adesão ou em que alguma parte se encontre em manifesta situação de vulnerabilidade" ${ }^{16}$. O conteúdo material do acordo, de igual modo, não pode violar a ordem pública e as leis vigentes ${ }^{17}$.Por fim, as limitações externas seriam as normas provenientes de outras fontes normativas, como o Código Civil e a própria Constituição da República. O Código Civil é particularmente importante porque disciplina as condições de validade da manifestação de vontade e as condições de validade dos negócios jurídicos ${ }^{18}$. A Constituição da República, por sua vez, funciona como matriz de interpretação e como moldura normativa que prevalecem em face da autonomia do indivíduos ${ }^{19}$.

\subsection{Princípio da boa-fé}

O princípio da boa-fé está previsto apenas na Lei da Mediação ${ }^{20}$ e, assim como o princípio da autonomia da vontade das partes, é derivado do âmbito do Direito Civil. De modo amplo, ele costuma ser compreendido pela literatura jurídica em duas espécies complementares: uma de natureza subjetiva e outra de natureza objetiva.

Na espécie subjetiva, o princípio da boa-fé estabelece a necessidade de se "fazer uma análise da percepção individual do agente cuja conduta está sendo analisada, visando a verificar se este acreditava que tal agir era correto, mesmo que esse não seja o padrão de conduta normal do homem médio naquela situação" 21 .

Na espécie objetiva, o princípio da boa-fé é apresentado pelo Vocabulário Jurídico do STJ como uma "regra de conduta que se traduz em um dever de agir em conformidade com determinados padrões de honestidade, de forma a não frustrar a confiança depositada pela outra parte" ${ }^{22}$. Nesses termos, o princípio da boa-fé exerceria três funções distintas: uma função interpretativa, uma função corretiva e de controle de exercício de um direito e uma função de integração do negócio jurídico ${ }^{23}$. Na função interpretativa, derivada do art. 113 do Código Civil ${ }^{24}$, "a boa-fé significa um critério hermenêutico objetivo de que o juiz deve se valer na busca da supressão das lacunas da relação contratual, de forma a preservar as justas expectativas das partes

${ }^{16}$ Código de Processo Civil, art. 190, parágrafo único.

${ }^{17}$ Código de Ética de Conciliadores e Mediadores Judiciais, art. $1^{\circ}$, VI.

18 BRASIL. Lei $\mathbf{n}^{\mathbf{0}} \mathbf{1 0 . 4 0 6}$, de 10 de janeiro de 2002. Institui o Código Civil. Publicado no Diário Oficial da União de 11 de Janeiro de 2002. Disponível em 〈> Acesso em 13 de maio de 2017. Arts. 104 a 184, por exemplo.

19 Sobre a limitação da autonomia da vontade em uma perspectiva constitucional, ver, por exemplo, FACHIN, Luiz Edson; GONÇALVES, Marcos Alberto Rocha. Hermenêutica da autonomia da vontade como princípio informador da mediação e conciliação. Revista de Informação Legislativa, Brasília, ano 48, n. 190, abr./jun. 2011.

${ }^{20}$ Lei da Mediação, art. $2^{\circ}$, VIII.

${ }^{21}$ CAPIBERIBE, Denise de Araújo. O princípio da boa-fé objetiva e sua evolução doutrinária e jurisprudencial ao longo dos 10 anos de edição do Novo Código Civil. In: Vvaa. 10 anos do Código Civil: aplicação, acertos, desacertos e novos rumos. Série Aperfeiçoamento de Magistrados, no 13, V. I.. Rio de Janeiro: EMERJ, 2013. Disponível em <http://www.emerj.tjrj.jus.br/serieaperfeicoamentodemagistrados/paginas/series/13/volumeI/10anosdocodigocivil.pdf> Acesso em: 07 out. 2016. p. 119.

${ }^{22}$ STJ. Princípio da boa-fé objetiva. Vocabulário Jurídico. Disponível em <http://www.stj.jus.br/SCON/servlet/ThesMain?action=consultar\&pesquisa=PRINC\%CDPIO $>$ Acesso em: 15 out. 2016.

${ }^{23}$ CAPIBERIBE, 2013, p. 119-120.

${ }^{24}$ Código Civil, art. 113. Os negócios jurídicos devem ser interpretados conforme a boa-fé e os usos do lugar de sua celebração. 
contratantes" 25 . Na função corretiva, derivada do art. 187 do Código Civil ${ }^{26}$, "a boa-fé assume função semelhante à figura do abuso de direito, não admitindo condutas que contrariem o dever de agir com lealdade e probidade, pois somente assim o contrato alcançará a função social dele esperada" 27 . Na função integrativa, derivada do art. 442 do Código Civil ${ }^{28}$, o princípio da boa-fé "visa a criar deveres anexos que devem ser observados pelos contratantes em todas as fases do contrato, inclusive, na fase pré-contratual e pós-contratual, porquanto os efeitos do contrato se protraem no tempo" 29 .

Pelo exposto, o princípio da boa-fé parece ser plenamente aplicável em suas modalidades subjetiva e objetiva ao procedimento da mediação. Na modalidade subjetiva, o princípio põe em relevo o dever do mediador esclarecer equívocos sobre fatos ou direitos que ele perceber nas afirmações ou crenças de uma ou de ambas as partes. Trata-se da reafirmação do seu dever de buscar o entendimento e o consenso e facilitar a resolução do conflito ${ }^{30}$, auxiliando os "interessados a compreender as questões e os interesses em conflito" "31. Na modalidade objetiva, o princípio da boa-fé impõe ao mediador o dever de zelar pela manutenção da honestidade recíproca entre as partes - tanto na condução da mediação como na interpretação das questões subjacentes ao conflito e dos termos do acordo entabulado.

\subsection{Princípio da busca do consenso}

O princípio da busca do consenso está previsto apenas na Lei da Mediação ${ }^{32}$. De forma ampla e em usos cotidianos, o termo consenso comporta quatro significados distintos. Ele pode significar S1) "concordância ou uniformidade de opiniões, pensamentos, sentimentos, crenças etc.", S2) deliberação na qual "não há objeções ou argumentos contrários ao que se está propondo", S3) "bom senso, senso comum" ou S4) "anuência; consentimento" "33. No campo jurídico, ele costuma ser usado na forma da expressão "mútuo consenso" para designar um S5) "acordo recíproco das partes para se fazer ou desfazer um negócio jurídico; mútuo consentimento" 34 .

Traduzindo e sistematizando essas definições para o âmbito da mediação, o princípio da busca do consenso pode ser compreendido em duas perspectivas distintas: P1) a busca da compreensão mútua sobre fatos e direitos relevantes no conflito (tal como em S1 e S3) ou P2) a busca pelo acordo mutuamente consentido (tal como em S2, S4 e S5). A interpretação do princípio da busca do consenso nessas duas perspectivas encontra sustentação em outro enunciado da própria Lei da Mediação que estabelece que "o mediador conduzirá o procedimento de comunicação entre as partes, buscando o entendimento e o consenso e facilitando a resolução do conflito" 35 .

${ }^{25}$ CAPIBERIBE, 2013, p. 120.

${ }^{26}$ Código Civil, art. 187. Também comete ato ilícito o titular de um direito que, ao exercê-lo, excede manifestamente os limites impostos pelo seu fim econômico ou social, pela boa-fé ou pelos bons costumes.

${ }^{27}$ CAPIBERIBE, 2013, p. 120.

${ }^{28}$ Código Civil, art. 422. Os contratantes são obrigados a guardar, assim na conclusão do contrato, como em sua execução, os princípios de probidade e boa-fé.

${ }^{29}$ CAPIBERIBE, 2013, p. 120.

${ }^{30}$ Lei da Mediação, art. $4^{\circ}, \S 1^{\circ}$.

${ }^{31}$ Código de Processo Civil, art. $165, \S 3^{\circ}$.

${ }^{32}$ Lei da Mediação, art. $2^{\circ}$, VI.

${ }^{33}$ INSTITUTO ANTÔNIO HOUAISS. Houaiss eletrônico. Versão monousuário 3.0 [CD-ROM]. Rio de Janeiro: Editora Objetiva Ltda., 2009. Definições 1, 1.1, 2 e 4, respectivamente, do termo consenso.

${ }^{34}$ HOUAISS, 2009, locução "mútuo consentimento" do termo consenso.

${ }^{35}$ Lei da Mediação, art. $4^{\circ}, \S 1^{\circ}$. 
Embora semelhantes à primeira vista, essas perspectivas implicam conteúdos normativos diversos. Em P1, o princípio da busca do consenso significaria um dever atribuído ao mediador de esclarecer ou estimular o esclarecimento de mal-entendidos e incompreensões subjacentes ao conflito. Esse esclarecimento pode viabilizar a composição consensual ou não. Em P2, o significado normativo do princípio da busca do consenso diz respeito ao próprio dever de promover a composição do conflito.

É interessante notar que o princípio da busca do consenso, compreendido tal como em $\mathrm{P} 2$, pode ser subvertido pelo estímulo que o mediador tem de alcançar o maior número possível de acordos para favorecer a sua própria avaliação profissional ${ }^{36}$. As partes, em especial aquelas provenientes de camadas sociais privadas de recursos econômicos e culturais, podem perceber a insistência do mediador em estabelecer o acordo como a única ou a melhor saída para o conflito.

Genacéia da Silva Alberton, na qualidade de coordenadora do Núcleo de Estudos de Mediação da Escola Superior da Magistratura do Rio Grande do Sul, opinou pela exclusão do princípio da busca do consenso da Lei da Mediação por uma constatação semelhante. Para ela, o princípio "faz parte de todo o procedimento autocompositivo e não é essencial para a mediação. Uma mediação pode ser inexitosa e ter uma repercussão positiva para os envolvidos com restauração do diálogo. A mediação, portanto, não pode e não deve ser medida unicamente pelo êxito constante no Termo de Entendimento" 37 .

\subsection{Princípio da competência}

O princípio da competência está previsto apenas no Código de Ética de Conciliadores e Mediadores Judiciais, Anexo III da Resolução no 125/2010 do CNJ, que define o seu conteúdo normativo como o dever do mediador "de possuir qualificação que o habilite à atuação judicial" e de se submeter à "reciclagem periódica obrigatória para formação continuada" 38 . Na verdade, portanto, o princípio da competência prescreve dois deveres aos mediadores: o primeiro é o de se qualificar e o segundo é o de se reciclar periodicamente.

A qualificação de mediadores referida pelo princípio da competência é especificada na Resolução n. 125/2010 do CNJ, no Código de Processo Civil e na Lei da Mediação. De acordo com a Resolução ${ }^{\circ}$ 125/2010 do CNJ, a competência é comprovada por certificado de conclusão de curso promovido pelos tribunais ou instituições parceiras e que contemple o conteúdo programático do Anexo I da própria Resolução ${ }^{39}$.

\footnotetext{
${ }^{36}$ Como estabelece o art. 167, $\S \S 3^{\circ}$ e $4^{\circ}$, do Código de Processo Civil: “[...] do cadastro de conciliadores e mediadores constarão todos os dados relevantes para a sua atuação, tais como [...] o sucesso ou insucesso da atividade, [...] classificados sistematicamente pelo tribunal, que os publicará, ao menos anualmente, para conhecimento da população e para fins estatísticos e de avaliação [...] dos conciliadores e dos mediadores".

37 ALBERTON, Genacéia da Silva. O Núcleo de Estudos no contexto da mediação no Rio Grande do Sul e as proposições legislativas na área da mediação. Revista Multijuris, $\mathrm{n}^{\circ}$ 13, ano IX, dez./2014. p. 4. Disponível em <http:// www.ajuris.org.br/sitenovo/wp-content/uploads/2014/12/O-NUCLEO-DE-ESTUDOS-NO-CONTEXTO-DA-MEDIACAO.pdf> Acesso em: 20 out. 2016.

${ }^{38}$ Código de Ética de Conciliadores e Mediadores Judiciais, art. $1^{\circ}$, III.

${ }^{39}$ Código de Ética de Conciliadores e Mediadores Judiciais, art. 12. Nos Centros, bem como todos os demais órgãos judiciários nos quais se realizem sessões de conciliação e mediação, somente serão admitidos mediadores e conciliadores capacitados na forma deste ato (Anexo I), cabendo aos Tribunais, antes de sua instalação, realizar o curso de capacitação, podendo fazê-lo por meio de parcerias. [...] $\S 2^{\circ}$ Todos os conciliadores, mediadores e outros especialistas em métodos consensuais de solução de conflitos deverão submeter-se a aperfeiçoamento permanente e a avaliação do usuário.
} 
O Código de Processo Civil possui um sentido semelhante, mas difere ao exigir o credenciamento e não a parceria das instituições ofertantes dos cursos de capacitação de mediadores ${ }^{40}$.

A Lei da Mediação também inova ao trazer outro requisito para a atuação dos mediadores em âmbito judicial: possuir graduação "há pelo menos dois anos em curso de ensino superior de instituição reconhecida pelo Ministério da Educação"41. Além disso, a Lei da Mediação também difere ao exigir que a instituição ofertante do curso de capacitação seja apenas reconhecida pela Escola Nacional de Formação e Aperfeiçoamento de Magistrados.

Por fim, cumpre observar que a dispensa de apresentação de certificado de conclusão de curso de capacitação dos mediadores que receberam qualificação dos tribunais antes da publicação da Resolução no 125/2010 do CNJ não faz muito sentido, pois a mesma norma estabelece obrigatoriedade de concluir cursos de treinamento e aperfeiçoamento, também oferecidos nos termos do Anexo I da Resolução, como requisito para atuação em âmbito judicial ${ }^{42}$.

\subsection{Princípio da confidencialidade}

O princípio da confidencialidade está previsto na Resolução no 125/2010 do CNJ, no Código de Processo Civil e na Lei da Mediação.

A Resolução no 125/2010 do CNJ, no seu Anexo III - Código de Ética de Conciliadores e Mediadores Judiciais, estabelece o conteúdo normativo desse princípio como o dever do mediador de "manter sigilo sobre todas as informações obtidas na sessão, salvo autorização expressa das partes, violação à ordem pública ou às leis vigentes, não podendo ser testemunha do caso, nem atuar como advogado dos envolvidos, em qualquer hipótese" 43 .

O Código de Processo Civil enumera o princípio da confidencialidade como um dos informativos da mediação ${ }^{44}$ e estabelece o seu conteúdo normativo ao prescrever que o dever de confidencialidade "estende-se a todas as informações produzidas no curso do procedimento, cujo teor não poderá ser utilizado para fim diverso daquele previsto por expressa deliberação das partes" 45 . Além disso, embora não com o nome de princípio da confidencialidade, o Código de Processo Civil prescreve que, em razão do dever de sigilo inerente às suas funções, mediadores, conciliadores e membros de suas equipes "não poderão divulgar ou depor acerca de fatos ou elementos oriundos da conciliação ou da mediação" .

A Lei da Mediação afirma o princípio da confidencialidade como um dos orientadores da mediação ${ }^{47}$ e, de modo a tornar inequívoco o seu conteúdo normativo, lhe confere uma seção específica $^{48}$. Esse princípio estabelece o dever de tornar confidencial toda e qualquer informação

${ }^{40}$ Código de Processo Civil, art. $167, \S 1^{\circ}$ Preenchendo o requisito da capacitação mínima, por meio de curso realizado por entidade credenciada, conforme parâmetro curricular definido pelo Conselho Nacional de Justiça em conjunto com o Ministério da Justiça, o conciliador ou o mediador, com o respectivo certificado, poderá requerer sua inscrição no cadastro nacional e no cadastro de tribunal de justiça ou de tribunal regional federal.

${ }^{41}$ Lei da Mediação, art. 11.

${ }^{42}$ Código de Ética de Conciliadores e Mediadores Judiciais, art. 12, §1 ${ }^{\circ}$. Os tribunais que já realizaram a capacitação referida no caput poderão dispensar os atuais mediadores e conciliadores da exigência do certificado de conclusão do curso de capacitação, mas deverão disponibilizar cursos de treinamento e aperfeiçoamento, na forma do Anexo I, como condição prévia de atuação nos Centros.

${ }^{43}$ Código de Ética de Conciliadores e Mediadores Judiciais, art. $1^{\circ}$, I.

${ }^{44}$ Código de Processo Civil, art. 166.

${ }^{45}$ Código de Processo Civil, art. 166, $\$ 1^{\circ}$.

${ }^{46}$ Código de Processo Civil, art. 166, $\$ 2^{\circ}$.

${ }^{47}$ Lei da Mediação, art. $2^{\circ}$, VII.

${ }^{48}$ Lei da Mediação, Capítulo I - Da Mediação, Seção IV - Da Confidencialidade e suas Exceções. 
relativa ao procedimento de mediação “em relação a terceiros, não podendo ser revelada sequer em processo arbitral ou judicial salvo se as partes expressamente decidirem de forma diversa ou quando sua divulgação for exigida por lei ou necessária para cumprimento de acordo obtido pela mediação"49.

O dever de confidencialidade impõe-se não apenas ao mediador, mas também “às partes, a seus prepostos, advogados, assessores técnicos e a outras pessoas de sua confiança que tenham, direta ou indiretamente, participado do procedimento de mediação" 50 . Constitui informação confidencial no procedimento de mediação qualquer declaração, opinião, sugestão, promessa ou proposta formulada por uma parte à outra na busca de entendimento para o conflito; reconhecimento de fato por qualquer das partes no curso do procedimento de mediação; manifestação de aceitação de proposta de acordo apresentada pelo mediador; e documento preparado unicamente para os fins do procedimento de mediação ${ }^{51}$. Exceto se expressamente autorizado, as informações prestadas ao mediador por apenas uma parte em seções privadas são também protegidas pelo dever de confidencialidade, inclusive em relação às demais partes ${ }^{52}$.

O dever de confidencialidade não protege as informações relativas à ocorrência de crime de ação pública ${ }^{53}$ e não afasta o dever dos seus destinatários de prestar informações à administração tributária após o termo final da mediação, aplicando-se aos seus servidores a obrigação de manterem sigilo das informações compartilhadas nos termos do art. 198 do Código Tributário Nacional $^{54}$. Para que o princípio da confidencialidade seja observado e compreendido pelos atores envolvidos no procedimento da mediação, a Lei da Mediação prescreve também o dever do mediador de "alertar as partes acerca das regras de confidencialidade aplicáveis ao procedimento" no início da primeira reunião da mediação e sempre que julgar necessário ${ }^{55}$.

Ainda em respeito ao dever de confidencialidade, a Lei da Mediação estabelece que, em caso de mediação extrajudicial cuja previsão contratual não seja completa, deve-se observar, na ocasião da primeira reunião, a necessidade de "local adequado a uma reunião que possa envolver informações confidenciais" ${ }^{56}$. Por fim, a Lei da Mediação estabelece que não serão admitidas como prova em processo arbitral ou judicial as informações relativas ao procedimento de mediação caso utilizadas em desacordo com as regras de confidencialidade que as protegem ${ }^{57}$.

\subsection{Princípio da decisão informada}

O princípio da decisão informada está previsto no Código de Processo Civil no Código de Ética da Resolução no 125/2010 do CNJ e talvez seja aquele que tem o maior potencial de impacto na condução do procedimento da mediação. Enquanto o Código de Processo Civil apenas o prevê como um princípio orientador da mediação ${ }^{58}$, deixando o seu conteúdo normativo relativamente impreciso, o Código de Ética é mais específico e o define como o "dever de manter

\footnotetext{
49 Lei da Mediação, art. 30.

${ }^{50}$ Lei da Mediação, art. 30, $\S 1^{\circ}$.

51 Lei da Mediação, art. $30, \S 1^{\circ}$, incisos I a IV.

52 Lei da Mediação, art. 31.

${ }^{53}$ Lei da Mediação, art. 30, $\S 3^{\circ}$.

${ }^{54}$ Lei da Mediação, art. 30, $\$ 4^{\circ}$.

55 Lei da Mediação, art. 14.

${ }^{56}$ Lei da Mediação, art. 22, §2 , II.

${ }^{57}$ Lei da Mediação, art. 20, $\$ 2^{\circ}$.

${ }^{58}$ Código de Processo Civil, art. 166.
} 
o jurisdicionado plenamente informado quanto aos seus direitos e ao contexto fático no qual está inserido" $" 59$.

Ainda que outras interpretações possam ser conjecturadas, a definição que Código de Ética da Resolução no ${ }^{\circ}$ 125/2010 do CNJ confere ao princípio da decisão informada permite extrair claramente duas normas que podem, cada uma delas, orientar dois comportamentos distintos do mediador.

A primeira norma é extraída quando se assume que os "direitos" e o "contexto fático" de que trata o enunciado são os elementos que constituem apenas o procedimento da mediação. Nessa primeira interpretação, a norma seria compreendida como um dever atribuído ao mediador de informar as partes sobre as regras que regulamentam a mediação, como o dever de confidencialidade, as hipóteses de impedimento etc., bem como o contexto específico da mediação em relação ao processo judicial, caracterizado especialmente pela ausência de solução imposta por sentença.

A segunda interpretação, por sua vez, é aquela que assume que os "direitos" e o "contexto fático" do enunciado são relativos não apenas ao procedimento da mediação, mas também ao próprio conflito das partes. Aqui a norma seria compreendida como um dever atribuído ao mediador de esclarecer as partes sobre os elementos que configuram o conflito e os direitos que cada uma delas, em tese ${ }^{60}$, possui.

\subsection{Princípio do empoderamento}

O princípio do empoderamento está previsto apenas no Código de Ética de Conciliadores e Mediadores Judiciais, Anexo III da Resolução no 125/2010 do CNJ. De acordo com a própria Resolução, tal princípio deve ser entendido como o dever do mediador de "estimular os interessados a aprenderem a melhor resolverem seus conflitos futuros em função da experiência de

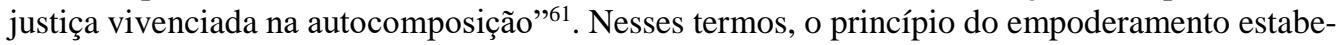
lece que a mediação deve ser uma oportunidade do mediador demonstrar às partes a) que é possível resolver conflitos futuros de forma consensual, b) como é possível resolvê-los e, principalmente, c) que é possível resolvê-los sem o auxílio do judiciário.

Ainda que o termo empoderamento tenha ganhado projeção apenas nos últimos anos no meio jurídico, ele é utilizado há algumas décadas em outros âmbitos. Ele é um conceito central em trabalhos do sociólogo Peter Berger ${ }^{62}$ e dos psicólogos americanos Julian Rappaport ${ }^{63}$ e Marc A. Zimmerman ${ }^{64}$, por exemplo. No Brasil, Paulo Freire dedicou certa atenção ao conceito de empowerment pelo menos desde $1986^{65}$.

${ }^{59}$ Código de Ética de Conciliadores e Mediadores Judiciais, art. $1^{\circ}$, II.

${ }^{60}$ A expressão "em tese" foi empregada propositalmente para sublinhar o fato de ser impossível reconhecer os direitos das partes antes da apreciação das provas e de um processo de cognição adequado

${ }^{61}$ Código de Ética de Conciliadores e Mediadores Judiciais, art. $1^{\circ}$, VII.

${ }^{62}$ Ver, porexemplo, BERGER, Peter Ludwig; NEUHAUS, Richard John. To Empower People: The Role of Mediating Structures in Public Policy. Washington: American Enterprise Institute for Public Policy Research, 1977.

63 Ver, porexemplo, RAPPAPORT, Julian. In Praise of Paradox: A Social Policy of Empowerment Over Prevention. American Journal of Community Psychology, vol. 9, n. I, 1981.

64 Ver, porexemplo, ZIMMERMAN, Marc A. Taking Aim on Empowerment Research: On the Distinction Between Individual and Psychological Conceptions. American Journal of Community Psychology, vol. 18, n. 1, 1990.

65 Ver, por exemplo, FREIRE, Paulo; SHOR, Ira. Medo e Ousadia: O Cotidiano do Professor. Trad. de Adriana Lopez. Rio de Janeiro: Paz e Terra, 1986. 
A definição que esses e outros acadêmicos atribuem ao termo empoderamento converge para a ideia de que é necessário aumentar o poder que os indivíduos têm para controlar os rumos de suas próprias vidas, inclusive os mais necessitados e aparentemente incapazes de atuação ${ }^{66}$. Isso não significa abandoná-los à própria sorte, mas municiá-los com competências e habilidades necessárias para exercerem a autonomia.

De certo modo, o conteúdo semântico do termo empoderamento se aproxima do princípio da autonomia da vontade, mas eles correspondem normas diversas enquanto princípios orientadores da mediação.

O princípio da autonomia da vontade, como já visto, reforça o dever de respeitar o caráter voluntário da escolha de se submeter à mediação, de modificar as regras do procedimento e de estabelecer o termo da composição do conflito.

O princípio do empoderamento, por outro lado, está ligado ao dever do mediador de estimular as partes a perceberem a experiência da mediação como uma experiência pedagógica, como um momento de aprendizado sobre as possibilidades de resolver conflitos futuros de forma consensual e sem o auxílio do judiciário.

\subsection{Princípio da imparcialidade}

O princípio da imparcialidade está previsto na Lei da Mediação (como princípio da imparcialidade do mediador) ${ }^{67}$, no Código de Processo Civil ${ }^{68}$ e na Resolução $n^{\circ}$ 125/2010 do $\mathrm{CNJ}^{69}$. O conceito e o conteúdo normativo do princípio da imparcialidade é estabelecido explicitamente no Código de Ética de Conciliadores e Mediadores Judiciais como o dever do mediador de "agir com ausência de favoritismo, preferência ou preconceito, assegurando que valores e conceitos pessoais não interfiram no resultado do trabalho, compreendendo a realidade dos envolvidos no conflito e jamais aceitando qualquer espécie de favor ou presente" ${ }^{" 70}$.

São deveres claros e objetivos, mas alguns dificilmente podem ser aplicados voluntariamente pelo mediador. O primeiro, o dever de agir com ausência de favoritismo e preferência, significa que o mediador não poderá conduzir o procedimento de modo a privilegiar uma das partes. O dever de recusar favores ou presentes é um complemento desse primeiro dever, pois a aceitação criaria a presunção de que o mediador se torna moralmente obrigado a retribuir à parte doadora. O segundo, o dever de agir com ausência de preconceito, pode ser compreendido como o dever do mediador de suspender juízos morais de qualquer natureza que eventualmente possa ter em relação a qualquer das partes com potencial de prejudicá-la. Os deveres de afastar valores e conceitos pessoais e de compreender a realidade dos envolvidos são complementos desse segundo dever.

O problema da aplicação voluntária dessas normas, observado no início do parágrafo anterior, se deve à dificuldade do mediador se perceber inclinado por preferência ou por preconceito. Obviamente, fala-se aqui do mediador que atua com a crença de estar em uma posição de neutralidade no conflito e não daquele que atua indevidamente mesmo se percebendo inclinado. De qualquer forma, tal dificuldade não prejudica a justificação do princípio da imparcialidade,

\footnotetext{
${ }^{66}$ RAPPAPORT, 1981, p. 15.

${ }^{67}$ Lei da Mediação, art. $2^{\circ}$, I.

${ }^{68}$ Código de Processo Civil, art. 166.

${ }^{69}$ Código de Ética de Conciliadores e Mediadores Judiciais, art. $1^{\circ}$, IV.

${ }^{70}$ Código de Ética de Conciliadores e Mediadores Judiciais, art. $1^{\circ}$, IV.
} 
pois as partes e os seus procuradores podem reivindicar a sua aplicação na hipótese do mediador não fazê-lo voluntariamente.

Embora não possam ser confundidos com o próprio princípio da imparcialidade, outros dispositivos trazidos pelos marcos normativos da mediação detalham, reforçam e conferem mais objetividade ao dever do mediador de se colocar em uma posição de neutralidade no conflito. $\mathrm{O}$ Código de Ética, por exemplo, estabelece impedimento ao mediador "de prestar serviços profissionais, de qualquer natureza, aos envolvidos em processo de conciliação/mediação sob sua condução"

Além disso, a Lei da Mediação ${ }^{72}$, o Código de Processo Civil ${ }^{73}$ e o Código de Ética estabelecem que aos mediadores são aplicados os mesmos motivos de impedimento ${ }^{74}$ e suspeição ${ }^{75}$ dos juízes. Assim como ocorre com os juízes, os motivos de impedimento tornam a parcialidade do mediador presumida e os motivos de suspeição colocam em dúvida a imparcialidade do mediador. Na ocorrência de qualquer motivo de impedimento ou suspeição, o Código de Ética estabelece o dever do mediador comunicar tal fato aos envolvidos, interromper a sessão e solicitar a sua substituição ${ }^{76}$.

O Código de Processo Civil, de igual modo, estabelece que o mediador deverá comunicar imediatamente a ocorrência de causa de impedimento ao juiz ou coordenador do CEJUSC para que se faça nova distribuição ${ }^{77}$. Caso o motivo de impedimento ou suspeição ${ }^{78}$ seja percebido durante o procedimento, o mediador deve interrompê-lo e solicitar distribuição para novo mediador, lavrando ata do ocorrido ${ }^{79}$.

${ }^{71}$ Código de Ética de Conciliadores e Mediadores Judiciais, art. $7^{\circ}$.

${ }^{72}$ Lei da Mediação, art. $5^{\circ}$.

73 Código de Processo Civil, art. 148, II.

74 As hipóteses de impedimento estão elencadas no Código de Processo Civil nos seguintes termos: Art. 144. Há impedimento do juiz, sendo-lhe vedado exercer suas funções no processo: I - em que interveio como mandatário da parte, oficiou como perito, funcionou como membro do Ministério Público ou prestou depoimento como testemunha; II - de que conheceu em outro grau de jurisdição, tendo proferido decisão; III - quando nele estiver postulando, como defensor público, advogado ou membro do Ministério Público, seu cônjuge ou companheiro, ou qualquer parente, consanguíneo ou afim, em linha reta ou colateral, até o terceiro grau, inclusive; IV - quando for parte no processo ele próprio, seu cônjuge ou companheiro, ou parente, consanguíneo ou afim, em linha reta ou colateral, até o terceiro grau, inclusive; V - quando for sócio ou membro de direção ou de administração de pessoa jurídica parte no processo; VI quando for herdeiro presuntivo, donatário ou empregador de qualquer das partes; VII - em que figure como parte instituição de ensino com a qual tenha relação de emprego ou decorrente de contrato de prestação de serviços; VIII em que figure como parte cliente do escritório de advocacia de seu cônjuge, companheiro ou parente, consanguíneo ou afim, em linha reta ou colateral, até o terceiro grau, inclusive, mesmo que patrocinado por advogado de outro escritório; IX - quando promover ação contra a parte ou seu advogado. § 1o Na hipótese do inciso III, o impedimento só se verifica quando o defensor público, o advogado ou o membro do Ministério Público já integrava o processo antes do início da atividade judicante do juiz. [...] § $30 \mathrm{O}$ impedimento previsto no inciso III também se verifica no caso de mandato conferido a membro de escritório de advocacia que tenha em seus quadros advogado que individualmente ostente a condição nele prevista, mesmo que não intervenha diretamente no processo.

75 As hipóteses de suspeição estão elencadas no Código de Processo Civil nos seguintes termos: Art. 145. Há suspeição do juiz: I - amigo íntimo ou inimigo de qualquer das partes ou de seus advogados; II - que receber presentes de pessoas que tiverem interesse na causa antes ou depois de iniciado o processo, que aconselhar alguma das partes acerca do objeto da causa ou que subministrar meios para atender às despesas do litígio; III - quando qualquer das partes for sua credora ou devedora, de seu cônjuge ou companheiro ou de parentes destes, em linha reta até o terceiro grau, inclusive; IV - interessado no julgamento do processo em favor de qualquer das partes. § 1o Poderá o juiz declarar-se suspeito por motivo de foro íntimo, sem necessidade de declarar suas razões.

${ }^{76}$ Código de Ética de Conciliadores e Mediadores Judiciais, art. $5^{\circ}$.

77 Código de Processo Civil, art. 170.

${ }^{78}$ Embora tais dispositivos do Código de Processo Civil façam referência apenas às causas de impedimento, é possível concluir que são também aplicáveis aos casos de suspeição, dado que a atuação do mediador impedido ou suspeito configura hipótese de exclusão de cadastro.

79 Código de Processo Civil, art. 170, parágrafo único. 
A Lei da Mediação, embora não repita os enunciados que prescrevem ações ao mediador que se perceba impedido ou suspeito, não é apenas compatível com o Código de Ética e o Código de Processo Civil, mas também inova ao criar outro dever ao mediador: o de "revelar às partes, antes da aceitação da função, qualquer fato ou circunstância que possa suscitar dúvida justificada em relação à sua imparcialidade para mediar o conflito, oportunidade em que poderá ser recusado por qualquer delas" $"$.

A arguição de impedimento e suspeição, obviamente, também pode ser feita pelas próprias partes. Caso o mediador atue quando impedido ou suspeito, terá a sua conduta apurada em processo administrativo que pode ensejar a sua exclusão ${ }^{81}$. A denúncia do seu impedimento ou suspeição pode ser feita por qualquer pessoa e não apenas as partes da mediação ${ }^{82}$.

\subsection{Princípio da independência}

O princípio da independência está previsto no Código de Processo Civil ${ }^{83}$ e no Código de Ética de Conciliadores e Mediadores (como princípio da independência e autonomia) ${ }^{84}$. O Código de Ética estabelece o seu conteúdo normativo como dever do mediador "de atuar com liberdade, sem sofrer qualquer pressão interna ou externa, sendo permitido recusar, suspender ou interromper a sessão se ausentes as condições necessárias para seu bom desenvolvimento, tampouco havendo dever de redigir acordo ilegal ou inexequível"85.

Trata-se de um enunciado que estabelece várias normas. A primeira norma que dele se pode extrair estabelece o dever (que também pode ser interpretado como um direito) do mediador conduzir o procedimento de composição consensual sem que as partes, procuradores, juízes, servidores e quaisquer outros façam exigências ou tenham condutas incompatíveis com o escopo e o ambiente da mediação.

Para que esse dever seja cumprido, o enunciado confere ao mediador a faculdade de suspender ou interromper a sessão e até mesmo de recusar-se de nela atuar. Por fim, o enunciado do princípio da independência desobriga o mediador do dever de redigir acordo ilegal ou que não possa ser cumprido.

Na prática, esse princípio também pode apresentar problemas de efetividade. O primeiro decorre do ranqueamento dos mediadores que considera, dentre uma série de critérios, o seu índice de sucesso e insucesso na atividade ${ }^{86}$. Isso pode fazer com que ele atue tendenciosamente para viabilizar a celebração do acordo mesmo quando as partes demonstrem desinteresse ou insatisfação com os termos.Em outras palavras, o próprio Código de Processo Civil cria um mecanismo de estímulo ao alcance de acordos que pode contrariar o princípio da independência.

O segundo problema decorre de uma questão de mesma natureza: os incentivos que os juízes recebem para promover a celebração de acordos em procedimentos consensuais ${ }^{87}$ podem

${ }^{80}$ Lei da Mediação, art. $5^{\circ}$, parágrafo único.

${ }^{81}$ Código de Processo Civil, art. 173, II.

${ }^{82}$ Código de Ética de Conciliadores e Mediadores Judiciais, art. $8^{\circ}$, parágrafo único.

${ }^{83}$ Código de Processo Civil, art. 166.

${ }^{84}$ Código de Ética de Conciliadores e Mediadores Judiciais, art. $1^{\circ}$

${ }^{85}$ Código de Ética de Conciliadores e Mediadores judiciais, art. $1^{\circ}, \mathrm{V}$.

${ }^{86}$ Código de Processo Civil, art. 167, $\$ \S 3^{\circ} \mathrm{e} 4^{\circ}$.

${ }^{87} \mathrm{O}$ art. $8^{\circ}$, $\S 8^{\circ}$, da Resolução $\mathrm{n}^{\circ} 125 / 2010$ do CNJ estabelece que, "para efeito de estatística de produtividade, as sentenças homologatórias prolatadas em processos encaminhados de ofício ou por solicitação ao Centro Judiciário de Conflitos e Cidadania reverterão ao juízo de origem, e as sentenças decorrentes da atuação pré-processual ao coordenador do Centro [Judiciário de Solução de Conflitos e Cidadania]”. O art. 6º, III, também da Resolução n 125/2010 
influenciar negativamente o procedimento da mediação como uma pressão externa. Por fim, tendo em vista que poderão atuar como mediadores judiciais pessoas que não são graduadas em Direito, a possibilidade de reconhecer a ilegalidade e inexequibilidade de um acordo é bastante reduzida.

\subsection{Princípio da informalidade}

O Princípio da informalidade está previsto no Código de Processo Civil ${ }^{88}$ e na Lei da Mediação ${ }^{89}$. Em sentido amplo, informalidade significa ausência de formalidade ${ }^{90}$, isto é, ausência de uma maneira previamente determinada pela qual os atos devem ser cumpridos ${ }^{91}$. Em sentido jurídico, o termo informalidade costuma ser definido como a ausência de um "conjunto de prescrições quanto ao ritual e procedimentos que devem ser observados na formação de um ato para que este produza efeitos jurídicos" ${ }^{\prime 92}$.

No contexto da mediação, obviamente, essa carga semântica precisa ser deflacionada. Não é possível entender a informalidade aqui como ausência de regras. A informalidade é limitada explicitamente por todas as normas cuja observância foi instituída como condição de validade da mediação. Constituem exemplos dessas limitações a norma que obriga a lavratura de termo final ${ }^{93}$, a norma que torna obrigatória a assistência de advogado ou defensor público na mediação judicial ${ }^{94}$, a norma que exige a licitude do acordo $^{95}$, a norma que estabelece o dever do mediador de revelar fatos que possam suscitar dúvidas quanto a sua imparcialidade, etc.

Ainda que ocupe um lugar residual na ordem de precedência normativa, o princípio da informalidade não deixa de ser relevante. Dado que a mediação foi concebida para favorecer um ambiente adequado ao restabelecimento do diálogo entre as partes, é importante compreender tal princípio como uma necessidade de remover obstáculos e protocolos não-obrigatórios que eventualmente comprometam a fluidez e a espontaneidade da comunicação, deixando aos envolvidos a maior margem de liberdade possível.

Nesse sentido, os envolvidos podem escolher, por exemplo, prorrogar o tempo do procedimento $^{96}$, a forma e a duração do uso da palavra nas sessões, a utilização de recursos audiovisuais ou de tecnologias de comunicação à distância e qualquer outra ação que favoreça um desfecho positivo. Elas são livres inclusive para definir as suas próprias regras de procedimento ${ }^{97}$, desde que, obviamente, não sejam ilegais.

do CNJ, "Para desenvolvimento dessa rede, caberá ao CNJ" essa pontuação pode ser considerada "nas promoções e remoções de magistrados pelo critério do merecimento".

${ }^{88}$ Código de Processo Civil, art. 166.

${ }^{89}$ Lei da Mediação, art. $2^{\circ}$, IV.

${ }^{90}$ HOUAISS, 2009, termo informalidade.

${ }^{91}$ HOUAISS, 2009, termo formalidade.

${ }^{92}$ HOUAISS, 2009, termo formalidade.

${ }^{93}$ Lei da Mediação, art. 20.

94 Lei da Mediação, art. 26.

${ }^{95}$ Código de Ética de Conciliadores e Mediadores Judiciais, art. 1º, VI.

${ }^{96}$ Lei da Mediação, art. 28.

${ }^{97}$ Código de Processo Civil, art. 166, §4 . 


\subsection{Princípio da isonomia entre as partes}

O princípio da isonomia entre as partes está previsto apenas na Lei da Mediação ${ }^{98}$. Em acepção ampla, isonomia significa "estado dos que são governados pelas mesmas leis" 99 . Enquanto termo jurídico, o princípio da isonomia é compreendido como um "princípio geral do direito segundo o qual todos são iguais perante a lei; não devendo ser feita nenhuma distinção entre pessoas que se encontrem na mesma situação" 100 . Considerando simultaneamente as acepções ampla e jurídica do termo isonomia, é possível extrair duas normas desse princípio.

A primeira é derivada da interpretação de isonomia em uma dimensão eminentemente formal, fazendo com o que o seu objetivo se aproxime do objetivo buscado pelo princípio da imparcialidade: o de não conferir tratamento diferenciado ou privilegiado a quaisquer das partes. Nesses termos, o conteúdo normativo do princípio da isonomia pode ser compreendido como o dever do mediador de conduzir a composição consensual de forma escrupulosa em relação a todas as partes, considerado-as sem qualquer distinção ou preferência.

Determinação semelhante se encontra no Código de Processo Civil na qualidade de norma fundamental, assegurando "às partes paridade de tratamento em relação ao exercício de direitos e faculdades processuais, aos meios de defesa, aos ônus, aos deveres e à aplicação de sanções processuais, competindo ao juiz zelar pelo efetivo contraditório" 101.

A segunda norma é derivada da interpretação do termo isonomia em uma dimensão material. Nesse sentido, o princípio estabelece um dever ao mediador de impedir que uma das partes se aproveite indevidamente das assimetrias econômicas e culturais para obter um acordo vantajoso.

Em outras palavras, o princípio exige que o mediador identifique se a escolha pela composição consensual tenha sido uma estratégia utilizada deliberadamente por uma das partes para obter vantagens que não teria em um julgamento. Caso verifique a instrumentalização indevida do procedimento, o mediador deve reforçar o esclarecimento das questões e os interesses em conflito $^{102}$ ou até mesmo lavrar o termo de encerramento da mediação por não se justificarem novos esforços para a obtenção de consenso ${ }^{103}$.

A interpretação do princípio da isonomia em um sentido material pode parecer incompatível com a sua interpretação formal e com o princípio da imparcialidade (que proíbem que qualquer das partes, mesmo a hipossuficiente, receba um tratamento privilegiado), bem como com o princípio da autonomia da vontade. Todavia, a interpretação da isonomia em sentido material não enseja uma intervenção paternalista, mas simplesmente a aplicação de outras normas que regulamentam a mediação de forma direta ou indireta.

O princípio da boa-fé ${ }^{104}$, como já visto, impõe ao mediador o dever de impedir condutas e ações desonestas das partes. O princípio da decisão informada, também comentado anteriormente, impõe ao mediador o dever manter as partes informadas quanto aos seus direitos e ao contexto fático no qual está inserido ${ }^{105}$. Além dessas normas internas, cabe destacar a incidência de outras normas externas que impedem que o procedimento seja subvertido. Cita-se, a título

\footnotetext{
98 Código de Ética de Conciliadores e Mediadores Judiciais, art. 2º II.

${ }^{99}$ HOUAISS, 2009, termo isonomia.

${ }^{100}$ HOUAISS, 2009, termo isonomia.

${ }^{101}$ Código de Processo Civil, art. $7^{\circ}$.

${ }^{102}$ Código de Processo Civil, art. $165, \S 3^{\circ}$.

${ }^{103}$ Lei da Mediação, art. 20.

${ }^{104}$ Lei da Mediação, art. $2^{\circ}$, VIII.

${ }^{105}$ Código de Ética de Conciliadores e Mediadores Judiciais, art. $1^{\circ}$, III, e Código de Processo Civil, art. 165, $3^{\circ}$.
} 
exemplificativo, a responsabilização do litigante de má-fé ${ }^{106}$ e a vedação do enriquecimento sem causa $^{107}$.

\subsection{Princípio da oralidade}

O princípio da oralidade está previsto no Código de Processo Civil ${ }^{108}$ e na Lei da Mediação ${ }^{109}$. Em sentido amplo, por oralidade se entende a "qualidade, estado ou condição do que é oral", "exposição oral; parte oral de um discurso"110. Em âmbito jurídico, pode ainda significar "procedimento exclusivamente verbal"111. É um princípio que complementa e é complementado pelo princípio da informalidade, cujo objetivo é o de proporcionar um ambiente adequado ao restabelecimento da comunicação e entendimento das partes.

Considerando o escopo negocial e informal das sessões de mediação, tal princípio pode ser interpretado como o dever do mediador de conduzir o procedimento de modo a estimular e não prejudicar a interação verbal entre as partes e procuradores. Perguntas, respostas, interrupções e reestabelecimento de diálogos, intervenções do mediador e de sua equipe, enfim, qualquer comunicação deve ser feita preferencialmente através da voz. Em princípio, apenas o acordo deve ser redigido de forma escrita, ficando todas as demais interações desobrigadas de tal formalidade.

Obviamente, ainda que o conteúdo normativo do princípio da oralidade tenha de ser reconhecido como um verdadeiro dever, ele precisa ser compreendido sistematicamente dentro dos marcos normativos da mediação. E isso implica o reconhecimento de que ele pode ser afastado em circunstâncias nas quais a comunicação meramente verbal prejudica ou impede a condução do procedimento. Além disso, o princípio da autonomia permite que as próprias partes estabelecem regras para que o procedimento seja minimamente oral ou para que todos os diálogos sejam feitos de forma escrita ou reduzidos a termo, tal como uma ata de reunião.

\subsection{Princípio do respeito à ordem pública e às leis vigentes}

O princípio do respeito à ordem pública e às leis vigentes está previsto apenas no Código de Ética, que define o seu conteúdo normativo como o "dever de velar para que eventual acordo entre os envolvidos não viole a ordem pública, nem contrarie as leis vigentes" ${ }^{112}$.

É evidente que o princípio tem o sentido de evitar que o acordo viole dois elementos distintos, a ordem pública e as leis vigentes, mas não é tão simples definir o que seja ordem pública e nem tornar efetiva a proteção às leis vigentes. Por essas e outras razões, trata-se de um princípio que merece uma atenção especial e distinta para cada um dos seus dois componentes.

\footnotetext{
${ }^{106} \mathrm{O}$ art. 80 do Código Processo Civil define como litigante de má-fé aquele que "I - deduzir pretensão ou defesa contra texto expresso de lei ou fato incontroverso; II - alterar a verdade dos fatos; III - usar do processo para conseguir objetivo ilegal; IV - opuser resistência injustificada ao andamento do processo; V - proceder de modo temerário em qualquer incidente ou ato do processo; VI - provocar incidente manifestamente infundado; VII - interpuser recurso com intuito manifestamente protelatório".

${ }^{107}$ Código Civil, art. 884.

${ }^{108}$ Código de Processo Civil, art. 166.

${ }^{109}$ Lei da Mediação, art. $2^{\circ}$, II.

${ }^{110}$ HOUAISS, 2009, termo oralidade.

${ }^{111}$ HOUAISS, 2009, termo oralidade.

${ }^{112}$ Código de Ética de Conciliadores e Mediadores Judiciais, art. $1^{\text {o }}$, VI.
} 


\subsubsection{Respeito à ordem pública}

De modo amplo, ordem pública significa o "conjunto de instituições e de regras destinadas a manter em um país o bom funcionamento dos serviços públicos, a segurança e a moralidade das relações entre particulares" ${ }^{113}$. Respeitar a ordem pública significa apenas respeitar um determinado conjunto de instituições e regras. Todavia, ainda que seja intuitivo identificar no caso concreto as instituições e regras que garantem o bom funcionamento dos serviços públicos e a segurança, não parece ser intuitiva a identificação das instituições e regras que garantem a moralidade das relações entre particulares. A propósito, não parece uma tarefa simples o ato de definir o que seja moralidade das relações entre particulares.

O conceito de ordem pública é reconhecidamente problemático. Alguns inclusive tentam conferir-lhe certa racionalidade ao limitar o seu alcance semântico ou subdividindo-o em diferentes perspectivas. Como observou Moreira Neto, por exemplo, a definição padrão da expressão ordem pública pode ser compreendida em um sentido material ou descritivo e em um sentido formal ou normativo ${ }^{114}$

Mesmo com tentativas de racionalização como essa, os significados do conceito de ordem pública permanecem demasiadamente amplos e imprecisos. O problema não é a amplitude ou a imprecisão do conceito em si, mas o que se pode fazer com um conceito assim. Na prática, o dever de proteção à ordem pública pode ser utilizado indevidamente como um argumento para justificar a imposição de toda sorte de preconceitos daquele que tem o poder de reivindicá-lo. Sob o argumento de proteger a ordem pública, o mediador ou o juiz podem se sentir livres para recusar, por exemplo, a homologação de acordos considerados imorais pela religião que professa - seja por algum atributo das partes ou pelo conteúdo do acordo.

Isso não significa, porém, que o conceito de ordem pública tenha conferido efetivamente esse tipo de discricionariedade a mediadores e juízes. O que se observa aqui é apenas a possibilidade de abusos a partir de um suposto dever de proteção da ordem pública. As partes e os seus procuradores devem se manter atentos à incidência indireta de outras normas na regulamentação do procedimento da mediação, como a proteção constitucional ao direito de liberdade ${ }^{115}$ e vedação constitucional ao preconceito e discriminação ${ }^{116}$.

\subsubsection{Respeito às leis vigentes}

O dever de impedir que o acordo entre as partes viole a legislação vigente é autoexplicativo: trata-se de um controle de legalidade. O problema é que a efetividade dessa norma fica limitada ao conhecimento que o mediador tem da legislação vigente, que pode ser pouco ou nenhum. O diploma de graduação em Direito não é requisito para a atuação do mediador e a

\footnotetext{
${ }^{113}$ HOUAISS, 2009, locução ordem pública do termo ordem.

${ }^{114}$ No sentido material, ou descritivo, a ordem pública é uma situação de fato, ocorrente numa sociedade, resultante da disposição harmônica dos elementos que nela interagem, de modo a permitir-lhe um funcionamento regular e estável, assecuratório da liberdade de cada um. No sentido formal, ou normativo, a ordem pública é um conjunto de valores, de princípios e de normas que se pretende devam ser observados numa sociedade, impondo uma disposição ideal dos elementos que nela interagem, de modo a permitir-lhe um funcionamento regular e estável, assecuratório da liberdade de cada um (MOREIRA NETO, Diogo de Figueredo. Revisão doutrinária dos conceitos de ordem pública e segurança pública: uma análise sistêmica. R. Inf. Legisl., Brasília, ano 25, nº 97, p. 143).

${ }^{115}$ BRASIL. Constituição da República Federativa do Brasil de 1988. Publicada no Diário Oficial da União de 5 out. 1988. Art. $5^{\circ}$.

${ }^{116}$ Constituição Federal, art. $3^{\circ}$, IV.
} 
grade curricular do curso de capacitação de mediadores não possui uma densidade adequada para uma tarefa como a de reconhecer ilegalidades.

Para que a norma tenha condições de produzir os efeitos esperados, torna-se necessário que o mediador estude previamente a legislação aplicável aos litígios e que gradativamente se especialize em determinadas áreas. Além disso, sempre deverá solicitar a admissão de outro mediador no procedimento quando "recomendável em razão da natureza e da complexidade do conflito" 117 .

Por fim, cabe mencionar a existência de um segundo filtro de legalidade, que é aquele exercido pelo juiz. Prevê o Código de Processo Civil que a autocomposição obtida em audiência de mediação judicial será reduzida a termo e homologada por sentença ${ }^{118}$. Esse procedimento pressupõe que o juiz leia o acordo e perceba eventuais ilegalidades.

Na Lei da Mediação a obrigatoriedade da homologação é determinada apenas para o consenso das partes que envolva direitos indisponíveis e transigíveis ${ }^{119}$.Nos demais casos, haverá homologação apenas se as partes fizerem solicitação expressa. Do contrário, a remessa dos autos será feita para o juiz para fins de arquivamento e não de homologação ${ }^{120}$. Neste ponto, não parece fazer muito sentido discutir se prevalece o Código de Processo Civil ou a Lei da Mediação, isto é, a homologação compulsória ou a homologação por requisição. O fato da Lei da Mediação desobrigar a homologação do acordo obviamente não desobriga o juiz de controlar os atos praticados sob sua responsabilidade.

\subsection{Princípio da validação}

O Princípio da validação está previsto apenas no Código de Ética. O seu conteúdo normativo é estabelecido como o "dever de estimular os interessados perceberem-se reciprocamente como serem humanos merecedores de atenção e respeito" ${ }^{121}$. Não é arriscado afirmar que tal princípio parece ser o que melhor reflete a pretensão de superar o conflito pelo reestabelecimento da comunicação das partes e pela compreensão das questões e dos interesses envolvidos. Da mesma forma, é o princípio que melhor reflete as limitações dessa concepção idealizada.

Certamente, um número significativo de litígios poderá ser resolvido a partir da intervenção de um terceiro que esclarece os elementos do conflito e se esforça para reestabelecer a comunicação entre as partes. Na prática, porém, a mediação será usada em larga escala para, desde o início, estimular a negociação de direitos entre as próprias partes e assim evitar que o conflito perdure e continue consumindo recursos do judiciário.

Essa constatação não é um juízo de valor. A negociação de direitos entre as partes pode ser vantajosa ou não. Importa é perceber que o princípio em questão - e a concepção idealizada da mediação - só encontra sentido em um número reduzido de conflitos, que são aqueles nos quais a reaproximação das partes é determinante para a composição, como disputas entre vizinhos, colegas de trabalho ou familiares. Nos demais casos, ou princípio é irrelevante ou deve ser compreendido como mero dever de urbanidade.

\footnotetext{
${ }^{117}$ Lei da Mediação, art. 15.

${ }^{118}$ Código de Processo Civil, art. 334, $\$ 11$.

${ }^{119}$ Lei da Mediação, art. $3^{\circ}, \S 2^{\circ}$.

${ }^{120}$ Lei da Mediação, art. 28, parágrafo único.

${ }^{121}$ Código de Ética de Conciliadores e Mediadores Judiciais, art. $1^{\circ}$, VIII.
} 
É embaraçoso pensar, por exemplo, que o mediador conseguirá estimular os representantes legais de uma empresa de grande porte, que são profissionais remunerados para minimizar perdas econômicas da representada, perceberem a parte contrária como merecedora de atenção e respeito. Esses representantes até podem ser muito cordiais com a parte adversária, mas dificilmente farão concessões ao perceber que estão diante de uma pessoa merecedora de atenção e respeito.

É ainda mais embaraçoso pensar o contrário, que o mediador tem o dever de estimular, por exemplo, uma idosa a perceber como humana e merecedora de atenção e respeito uma empresa de plano de saúde ${ }^{122}$, já reputada como uma das maiores litigantes da cidade de São Paulo $^{123}$, que lhe negou prestar os serviços contratados em um momento delicado.

\section{CONCLUSÃO}

Como exposto nos tópicos precedentes, a compreensão dos princípios orientadores da mediação e dos seus respectivos conteúdos normativos é marcada por dificuldades que precisam ser consideradas e enfrentadas.

A primeira e mais evidente deriva do fato de a mediação ter sido tipificada em três distintos marcos - a Lei da Mediação, o Código de Processo Civil e a Resolução n. 125/2010 do CNJ. Embora cada um tenha vocação e abrangência específicas, eles atuam muitas vezes de forma simultânea na regulamentação de um mesmo ponto - como na própria definição dos princípios orientadores.

Além disso, foi observado que qualquer um desses marcos normativos pode não repetir exatamente os demais naquilo pretenderam regulamentar simultaneamente. Pode ocorrer, por exemplo, que uma aparente semelhança em enunciados induza conclusões equivocadas acerca da regulamentação de determinado aspecto da mediação.

Também parece ter ficado claro que o desempenho das tarefas atribuídas ao mediador, para se manter dentro da estrita legalidade, requer um conhecimento sobre o Direito que não se resume apenas ao conhecimento das técnicas e das normas que regulamentam a mediação. Como notado no estudo, os próprios princípios orientadores da mediação precisam ser entendidos dentro de um contexto normativo mais amplo e de forma sistemática. Isso porque alguns deles são complementados, limitados ou significativos apenas através de sua relação com outras normas externas à regulamentação da mediação.

Por fim, cabe ressaltar mais uma vez que o fato de a regulamentação da mediação ter sido realizada em um período relativamente recente, o estabelecimento dos conteúdos normativos dos seus enunciados, isto é, a identificação dos direitos e deveres por eles criados, será assentado gradativamente pela prática jurídica. Isso não significa que os dispositivos que regulamentam a mediação estão abertos a toda sorte de interpretações. Muitos dispositivos possuem significados

\footnotetext{
${ }^{122}$ STJ. Acordo bem-sucedido inaugura esforço do STJ pela mediação. Notícias. Disponível em <http:// www.stj.jus.br/sites/STJ/default/pt_BR/Comunica\%C3\%A7\%C3\%A3o/noticias/Not\%C3\%ADcias/Acordobem\%E2\%80\%93sucedido-inaugura-esfor\%C3\%A7o-do-STJ-pela-media\%C3\%A7\%C3\%A3o> Acesso em: 2 out. 2016.

${ }^{123}$ MIGALHAS. TJ/SP divulga lista das 100 instituições com mais processos na Justiça Estadual. Disponível em <http://www.migalhas.com.br/Quentes/17,MI118360,11049-TJSP+divulga+lista+das+100+instituicoes+com+mais+processos+na+Justica> Acesso em: 1 out. 2016. O anexo da notícia que contem a lista dos 100 maiores litigantes da cidade de São Paulo pode ser acessada diretamente pelo endereço <http://www.migalhas.com.br/ arquivo_artigo/art20100930-04.pdf>.
} 
normativos já sedimentados, restando apenas adaptá-los ao procedimento e ao escopo da mediação. Nessa tarefa de adaptação, de igual modo, os limites normativos também já se encontram inscritos dentro dos limites dos significados linguísticos dos seus enunciados.

\section{REFERÊNCIAS}

ALBERTON, Genacéia da Silva. O Núcleo de Estudos no contexto da mediação no Rio Grande do Sul e as proposições legislativas na área da mediação. Revista Multijuris, ${ }^{\circ}$ 13, ano IX, dez./2014. p. 4. Disponível em <http://www.ajuris.org.br/sitenovo/wp-content/uploads/2014/12/ O-NUCLEO-DE-ESTUDOS-NO-CONTEXTO-DA-MEDIACAO.pdf $>$ Acesso em: 20 out. 2016.

BERGER, Peter Ludwig; NEUHAUS, Richard John. To Empower People: The Role of Mediating Structures in Public Policy. Washington: American Enterprise Institute for Public Policy Research, 1977.

BRASIL. Lei $\mathbf{n}^{\mathbf{0}} \mathbf{1 0 . 4 0 6}$, de 10 de janeiro de 2002. Institui o Código Civil. Publicado no Diário Oficial da União de 11 de Janeiro de 2002.

. Lei no 13.105, de 16 de março de 2015. Código de Processo Civil. Publicado no Diário Oficial da União de 17 de março de 2015. Disponível em <http://www.planalto.gov.br/ccivil_03/ _ato2015-2018/2015/lei/113105.htm>. Acesso em 13 mai. 2017. Art. 166.

Lei $\mathbf{n}^{\mathbf{0}}$ 13.140, de 26 de junho de 2015. Dispõe sobre a mediação entre particulares como meio de solução de controvérsias e sobre a autocomposição de conflitos no âmbito da administração pública. Publicada no Diário Oficial da União de 29 de junho de 2015. Disponível em <http://www.planalto.gov.br/ccivil_03/_Ato2015-2018/2015/Lei/L13140.htm>. Acesso em 13 mai. 2017. Art. $2^{\text {a }}$, incisos I a VIII.

CAPIBERIBE, Denise de Araújo. O princípio da boa-fé objetiva e sua evolução doutrinária e jurisprudencial ao longo dos 10 anos de edição do Novo Código Civil. In: Vvaa. 10 anos do Código Civil: aplicação, acertos, desacertos e novos rumos. Série Aperfeiçoamento de Magistrados, n. 13, v. I.. Rio de Janeiro: EMERJ, 2013. Disponível em <http://www.emerj.tjrj.jus.br/ serieaperfeicoamentodemagistrados/paginas/series/13/volumeI/10anosdocodigocivil.pdf $>$ Acesso em: 07 out. 2016. p. 119

CNJ. Resolução no 125, de 29 de novembro de 2010. Dispõe sobre a Política Judiciária Nacional de tratamento adequado dos conflitos de interesses no âmbito do Poder Judiciário e dá outras providências. Disponível em <http://www.cnj.jus.br/busca-atos-adm?documento=2579> . Acesso em 13 mai. 2017 [Anexo III - Código de Ética de Conciliadores e Mediadores Judiciais, art. $1^{\circ}$ ]

FACHIN, Luiz Edson; GONÇALVES, Marcos Alberto Rocha. Hermenêutica da autonomia da vontade como princípio informador da mediação e conciliação. Revista de Informação Legislativa, Brasília, ano 48, n. 190, abr./jun. 2011.

FREIRE, Paulo; SHOR, Ira. Medo e Ousadia: O Cotidiano do Professor. Trad. de Adriana Lopez. Rio de Janeiro: Paz e Terra, 1986.

INSTITUTO ANTÔNIO HOUAISS. Houaiss eletrônico. Versão monousuário 3.0 [CD-ROM]. Rio de Janeiro: Editora Objetiva Ltda., 2009.

KELSEN, Hans. Teoria Pura do Direito. 6. ed. Trad. João Baptista Machado. São Paulo: Martins Fontes. 1998. 
MEIRA, Danilo Christiano Antunes. RODRIGUES, Horácio Wanderlei. Os marcos normativos da mediação entre particulares no âmbito civil: escopo e relações de complementariedade, subsidiariedade e incompatibilidade. R. Jur. FA7, Fortaleza, v. 13, n. 2, p. 117-137, jul./dez. 2016. MIGALHAS. TJ/SP divulga lista das 100 instituições com mais processos na Justiça Estadual. Disponível em <http://www.migalhas.com.br/Quentes/17,MI118360,11049-TJSP+divulga+lista+das+100+instituicoes+com+mais+processos+na+Justica> Acesso em: 1 out. 2016.

MOREIRA NETO, Diogo de Figueredo. Revisão doutrinária dos conceitos de ordem pública e segurança pública: uma análise sistêmica. R. Inf. Legisl., Brasília, ano 25, nº 97, p. 143

RAPPAPORT, Julian. In Praise of Paradox: A Social Policy of Empowerment Over Prevention. American Journal of Community Psychology, vol. 9, n. I, 1981.

STJ. Acordo bem-sucedido inaugura esforço do STJ pela mediação. Notícias. Disponível em <http://www.stj.jus.br/sites/STJ/default/pt_BR/Comunica\%C3\%A7\%C3\%A3o/noticias/ Not\%C3\%ADcias/Acordo-bem\%E2\%80\%93sucedido-inaugura-esfor\%C3\%A7o-do-STJ-pelamedia\%C3\%A7\%C3\%A3o> Acesso em: 2 out. 2016.

Princípio da autonomia da vontade das partes. Vocabulário Jurídico. Disponível em <http://www.stj.jus.br/SCON/servlet/ThesMain?action=consultar\&pesquisa $=$ PRINC\%CDPIO $\% 20 D A \% 20 A U T O N O M I A \% 20 D A \% 20 \mathrm{VON}-$

TADE\%20DAS\%20PARTES> Acesso em: 22 out. 2016.

. Princípio da boa-fé objetiva. Vocabulário Jurídico. Disponível em <http:// www.stj.jus.br/SCON/servlet/ThesMain?action=consultar\&pesquisa=PRINC\%CDPIO >. Acesso em: 15 out. 2016.

ZIMMERMAN, Marc A. Taking Aim on Empowerment Research: On the Distinction Between Individual and Psychological Conceptions. American Journal of Community Psychology, v. 18, n. 1, 1990.

Recebido em: 2 jul. 2017.

Aceito em: 14 nov. 2017. 